\title{
Dynamics of eicosanoids in peripheral blood cells during bronchial provocation in aspirin-intolerant asthmatics
}

\author{
D. Schäfer*, M. Schmid**, U.C. Göde**, H-W. Baenkler*
}

\begin{abstract}
Dynamics of eicosanoids in peripheral blood cells during bronchial provocation in aspirinintolerant asthmatics. D. Schäfer, M. Schmid, U.C. Göde, H-W. Baenkler. (C) ERS Journals Ltd 1999.

ABSTRACT: The underlying mechanisms of bronchoconstriction in aspirin-intolerant asthmatics (AIAs) are still unknown, but the hypothesis of an altered metabolism of arachidonic acid is generally accepted. So far, no in vitro test for aspirin intolerance is available. The hypothesis that the profile of eicosanoid mediators is changed in AIA-even before aspirin challenge was tested.

The release of prostaglandin $\mathrm{E}_{2}\left(\mathrm{PGE}_{2}\right)$, peptidoleukotrienes and histamine was measured using competitive enzyme immunoassays in 10 asthmatics with a history of aspirin intolerance, 10 controls and eight aspirin-tolerant asthmatics (ATAs) before and after bronchial provocation with lysine-aspirin.

Comparing basal release of eicosanoids before challenge, peptidoleukotrienes were significantly elevated and PGE $_{2}$ was vastly reduced in AIAs, whereas ATAs had elevated basal peptidoleukotrienes but only slightly reduced basal PGE $_{2}$. The decrease in forced expiratory volume in one second (FEV1) was not associated with changes in histamine release. After aspirin challenge, there was a massive increase of already elevated peptidoleukotrienes in AIAs, but not in ATAs. Arachidonic acid-induced PGE $_{2}$ release in AIAs was not significantly changed, whereas it was significantly reduced in ATAs and healthy controls. Histamine release was unaffected by aspirin challenge in all three groups.

There is a typically altered profile of eicosanoids in aspirin-intolerant asthmatics which could make in vitro diagnosis of aspirin intolerance possible.

Eur Respir J 1999; 13: 638-646.
\end{abstract}

\begin{abstract}
*Medical Clinic III, Dept of Allergology, and **Dept of Otorhinolaryngology, Head and Neck Surgery University of Erlangen,
\end{abstract} Nuremberg, Germany.

Correspondence: D. Schäfer

Medizinische Klinik III

Abt. f. Allergologie

Krankenhausstr. 12

D 91054 Erlangen

Germany

Fax: 4991318533399

Keywords: Aspirin-induced asthma histamine

peptidoleukotrienes

human prostaglandin $\mathrm{E}_{2}$

Received: September 11998

Accepted after revision October 81998
Aspirin intolerance affects $\sim 10 \%$ of adult asthmatics. The full-blown triad of asthma, aspirin intolerance and nasal polyposis is usually associated with a severe type of asthma and frequently requires chronic treatment with glucocorticoids [1-3]. The pathogenesis of aspirin intolerance has not yet been clearly defined. On the one hand, inhibition of cyclooxygenase and lack of metabolites, e.g. prostaglandin $\mathrm{E}_{2}\left(\mathrm{PGE}_{2}\right)$, appears to initiate a chain of reactions [4]. On the other hand leukotrienes (metabolites of the 5-lipoxygenase pathway) are possible mediators of aspirin-induced asthma, because they have strong bronchoconstrictive effects [5]. Studies of aspirin-induced asthma focused on measuring mediators in bronchoalveolar lavage fluid [6], nasal secretion $[7,8]$, urinary excretion [9-11] or separated cells [12-14]. So far, no in vitro test for aspirin intolerance is available, and diagnosis relies on the history and different methods of provocation tests with variable sensitivity [15]. All these tests carry the risk of provoking a severe asthma attack.

Currently, many theories try to explain the symptoms of aspirin intolerance. Most theories are focused on the inhibition of cyclooxygenase [4]. Others postulate shunting of arachidonic acid from biosynthesis of prostaglandins to leukotrienes [13] or the modulation of the metabolism of neuropeptides and other mediators by $\mathrm{PGE}_{2}$ [16]. Furthermore, an albumin-binding property of analgesic drugs was reintroduced [17]. Thus, it is important to look not only at the lipoxygenase pathway alone, but to evaluate both interdependent pathways, i.e. the "profile" of eicosanoids, and also histamine, as it might play a role in the pathogenesis of asthma [18].

In the present study the dynamics of mediator release in peripheral blood cells (PBC) from aspirin-intolerant asthmatics (AIAs) during bronchial provocation with lysineaspirin was examined. To test the hypothesis that the profile of eicosanoid mediators is changed in AIA not only after, but also before, aspirin challenge, mediator release of PBC was compared to healthy subjects and aspirin-tolerant asthmatics (ATAs). The release of $\mathrm{PGE}_{2}$, peptidoleukotrienes (pLT) and histamine of PBC was measured to assess the role of the cyclooxygenase- and 5-lipoxygenase-pathway and the implication of histamine in a system with intact intercellular mechanisms. Thus, the long-term goal of the study was to check the possibility of a simple and cheap in vitro whole blood test for routine diagnosis of aspirin intolerance. For this purpose the study was not designed to identify the role of different cell types in aspirin intolerance. 


\section{Materials and methods}

\section{Subjects}

Normal subjects. Ten subjects (four male, six females) were studied, aged 22-38 yrs, who had no history of asthma or sensitivity to aspirin. Allergic disease was ruled out with a prick test. Sinusitis was ruled out by endoscopy. Four subjects were smokers and none were atopic.

Aspirin-intolerant asthmatics. Ten patients (three male, seven females) aged 20-58 yrs with classic symptoms of an aspirin triad were studied. They were selected on the basis of a previous severe asthma attack after ingestion of aspirin or another nonsteroidal anti-inflammatory drug and a decrease of forced expiratory volume in one second (FEV1) $>25 \%$ after bronchial provocation. All patients had recurrent chronic polypous sinusitis on nasoendoscopy. All of the patients had undergone previous surgery for polyposis. None of the patients received topical or systemic corticosteroid therapy during the last 14 days before the study. Therapy with antihistamines or cromolyn sodium was withheld for at least $24 \mathrm{~h}$ prior to the study.

Aspirin-tolerant asthmatics. Eight patients (four male, four female) aged 35-58 yrs with long-term intrinsic asthma were included as an additional control group. Allergy was ruled out by careful history taking, prick-test and radioallergosorbent test (RAST). All of the ATAs used inhalative $\beta$-sympathomimetics as regular medication. Five of the patients used inhalative corticosteroids (budesonide $0.2 \mathrm{mg} \cdot \mathrm{day}^{-1}$ b.i.d.), as an additional drug, infrequently prior to the study. At the time of examination none of the patients had used inhalative corticoids for at least four days. Aspirin intolerance was ruled out by oral provocation with a single dose of $500 \mathrm{mg}$ acetylsalicylic acid (ASA) under control with a pulmonary function analyser (Draeger, Lübeek, Germany). Oral provocation was only used for patients in control groups (ATAs, normal subjects) with absolutely no history of an adverse reaction to ASA.

\section{Inhalative provocation}

Aspirin challenges were performed as described by Schmitz-SchumanN et al. [19]. All subjects underwent bronchial provocation with lysine-aspirin (Aspisol; Bayer Leverkusen, Germany), which was diluted with saline to produce a range of increasing concentrations from 1.25 , $2.5,5.0,7.5,12.5$ to $25 \mathrm{mg} \cdot \mathrm{mL}^{-1}$. One millilitre was placed in a Heyer nebulizer, and the subjects inhaled via a mouthpiece during normal breathing. Measurements of airway parameters were performed with a pulmonary function analyser (Draeger), and the subjects were excluded if baseline FEV1 was $<65 \%$ of predicted value. If the decrease of FEV1 was $<10 \%$ after inhalation of normal saline, lysine-aspirin challenge was performed. Two measurements of FEV1 were made at 15 and 30 min after each dose of inhaled lysine-aspirin, and the maximum reading was recorded. If the decrease of FEV 1 was $<15 \%$, the next dose of lysine-aspirin was inhaled, until there was a $25 \%$ decrease of FEV1, or if there was a fall $\geq 15 \%$ with clinical signs of bronchial obstruction. This dose was considered the threshold dose. Pulmonary function was monitored for another $24 \mathrm{~h}$ with a peak-flow meter and measurement of FEV1.

\section{Cell preparation and experimental in vitro protocol}

Venous blood $(10 \mathrm{~mL})$ was collected before and after successful inhalative provocation in a $10 \mathrm{~mL}$ syringe containing 5\% heparin sodium (Promonta, Hamburg, Germany). Peripheral blood cells were prepared by dextran sedimentation (5\% dextran 500, GIBCO, Hamburg, Germany) for $60 \mathrm{~min}$ at $37^{\circ} \mathrm{C}$. The top layer was recovered, washed twice with phosphate-buffered saline (PBS) by centrifugation $\left(900 \times g\right.$ for $10 \mathrm{~min}$ at $\left.4^{\circ} \mathrm{C}\right)$ and the pellet was resuspensed in RPMI-1640 without foetal calf serum. A concentration of $10^{5} \mathrm{PBC} \cdot \mathrm{mL}^{-1}$ (in a volume of 250 $\mu \mathrm{L} \cdot \mathrm{well}^{-1}$ ) was incubated as a duplicate culture in 96-well flat bottom plates which had ultra low binding interactions (Corning Costar Co., Cambridge, USA) in a humidified $5 \% \mathrm{CO}_{2}$ /air mixture at $37^{\circ} \mathrm{C}$ for $20 \mathrm{~min}$ or as indicated. Adherence of cells was ruled out by light microscopy. Cells were separated using a standard Ficoll/Hypaquegradient centrifugation $\left(1,000 \times g, 40 \mathrm{~min}\right.$ at $\left.4^{\circ} \mathrm{C}\right)$. The upper layer of Percoll-gradient centrifugation $(400 \times g, 5$ min, $4^{\circ} \mathrm{C}$ ) was removed for monocyte/lymphocyte preparation and washed twice with PBS. The lower layer was recovered for granulocyte preparation and washed three times with PBS $\left(400 \times g, 5 \mathrm{~min}, 4^{\circ} \mathrm{C}\right)$ and erythrocytes were lysed by addition of distilled water ( $30 \mathrm{~s}$ on ice) and washing with PBS $\left(350 \times g, 5 \mathrm{~min}, 4^{\circ} \mathrm{C}\right)$. The pellet was resuspensed in RPMI-1640. The purity of the monocyte and polymorphonuclear granulocyte preparation was $>97 \%$ and $>95 \%$, respectively. The viability of cells was $>99 \%$ by trypan blue exclusion. Cell isolation revealed the absence of platelets, a source of $\mathrm{PGE}_{2}$ production. For basal mediator release, cells were incubated without any stimulants; induced mediator release was achieved by addition of $10^{-5} \mathrm{M}$ arachidonic acid, which proved to be an optimal concentration for this experimental procedure (fig. 1b). Additionally, calcium ionophore A23187 was tested with and without arachidonic acid. Eicosanoid release was lower using calcium ionophore alone compared to arachidonic acid. If both stimuli were used, a synergistic effect was observed resulting in a higher release of eicosanoids. However, the standard deviation of the measurements with calcium ionophore was higher, so that this stimulus was omitted.

Arachidonic acid is the main substrate for cyclooxygenase and 5-lipoxygenase and is released from its stores in tissue lipids by the action of phospholipase $\mathrm{A}_{2}\left(\mathrm{PLA}_{2}\right)$. $\mathrm{PLA}_{2}$ are a diverse family of regulatory enzymes which play a central role in the regulation of the biosynthesis of numerous lipid pro-inflammatory mediators. Its activity is calcium dependent [21]. As this study wanted to focus on the activation of cyclooxygenase and lipoxygenase, the complex regulation and interaction of $\mathrm{PLA}_{2}$ had to be bypassed. Therefore, arachidonic acid was chosen to be the optimal stimulus for induction of $\mathrm{pLT}$ and $\mathrm{PGE}_{2}$ release in these experiments. Arachidonic acid-induced histamine release was measured, to rule out the histamine-influence on arachidonic acid-induced $\mathrm{pLT}$ and $\mathrm{PGE}_{2}$ release. 
For in vitro inhibition experiments $\mathrm{PBC}$ were preincubated for $15 \mathrm{~min}$ with variable concentrations of $\mathrm{PGE}_{2}$, dibutyryl-cyclic adenosine monophosphate (cAMP), or caffeic acid $\left(10^{-5} \mathrm{M}\right)$. The incubation of $\mathrm{PBC}$ was terminated by centrifugation $\left(900 \times g, 7 \mathrm{~min}, 4^{\circ} \mathrm{C}\right)$ and supernatants were collected in 96-well flat bottom plates and frozen at $-80^{\circ} \mathrm{C}$ for up to four weeks until mediator quantification. The chemicals were purchased from Biomol (Hamburg, Germany).

\section{Quantification of mediators}

The release of immunoreactive $\mathrm{pLT}, \mathrm{PGE}_{2}$ and histamine was quantified simultaneously for each sample in duplicates by highly sensitive and specific competitive enzyme immunoassays (EIA) using formerly established and validated monoclonal antibodies for pLT [22] and $\mathrm{PGE}_{2}$ [23]. The cross-reactivities of the monoclonal pLTantibody were $95.7 \%, 100 \%$, and $88.7 \%$ for leukotriene (LT) $\mathrm{C}_{4}, \mathrm{LTD}_{4}$, and $\mathrm{LTE}_{4}$, respectively, those for the monoclonal $\mathrm{PGE}_{2}$-antibody were $100 \%$ and $5.54 \%$ for $\mathrm{PGE}_{2}$ and $\mathrm{PGE}_{1}$, respectively. For more detailed data on cross-reactivities for the other eicosanoids tested, see [22, 23]. The pLT- and $\mathrm{PGE}_{2}$-EIA were performed according to the protocols published recently [24], diluting standard and samples in RPMI-1640. The intra- and interassay variance for pLT-EIA were $9 \%$ and $7.5 \%$, respectively and for $\mathrm{PGE}_{2}$-EIA $8 \%$ and $6 \%$, respectively. The rate of recovery for $\mathrm{pLT}$ and $\mathrm{PGE}_{2}$ was $\geq 98 \%$ with a sensitivity of 1 $\mathrm{pg} \cdot \mathrm{mL}^{-1}$ for $\mathrm{pLT}$-EIA and $3 \mathrm{pg} \cdot \mathrm{mL}^{-1}$ for $\mathrm{PGE}_{2}$-EIA. Owing to the extremely low basal production of pLT these measurements were made in a range below the recommended sensitivity of the assay (values of basal pLT were in the range $>80 \% \mathrm{~B} / B_{0}$ at $1 \mathrm{pg} \cdot \mathrm{mL}^{-1}$ ). Histamine was measured by a commercially available histamine-EIA purchased from DIANOVA-Immunotech (Hamburg, Germany). The assay was performed according to the instructions of the company, diluting samples in RPMI1640. The results are presented in $\mathrm{pg} \cdot \mathrm{mL}^{-1}$.

\section{Data analysis}

The eicosanoid and histamine release values are expressed as arithmetic mean \pm SEM. The two-tailed t-test was used for statistical calculation on normally distributed data. Student's paired t-test was used to compare the stimulated mediator release within the subjects. The MannWhitney test was used to compare AIAs, ATAs and normal subjects. A p-value of $<0.05$ was regarded as statistically significant.
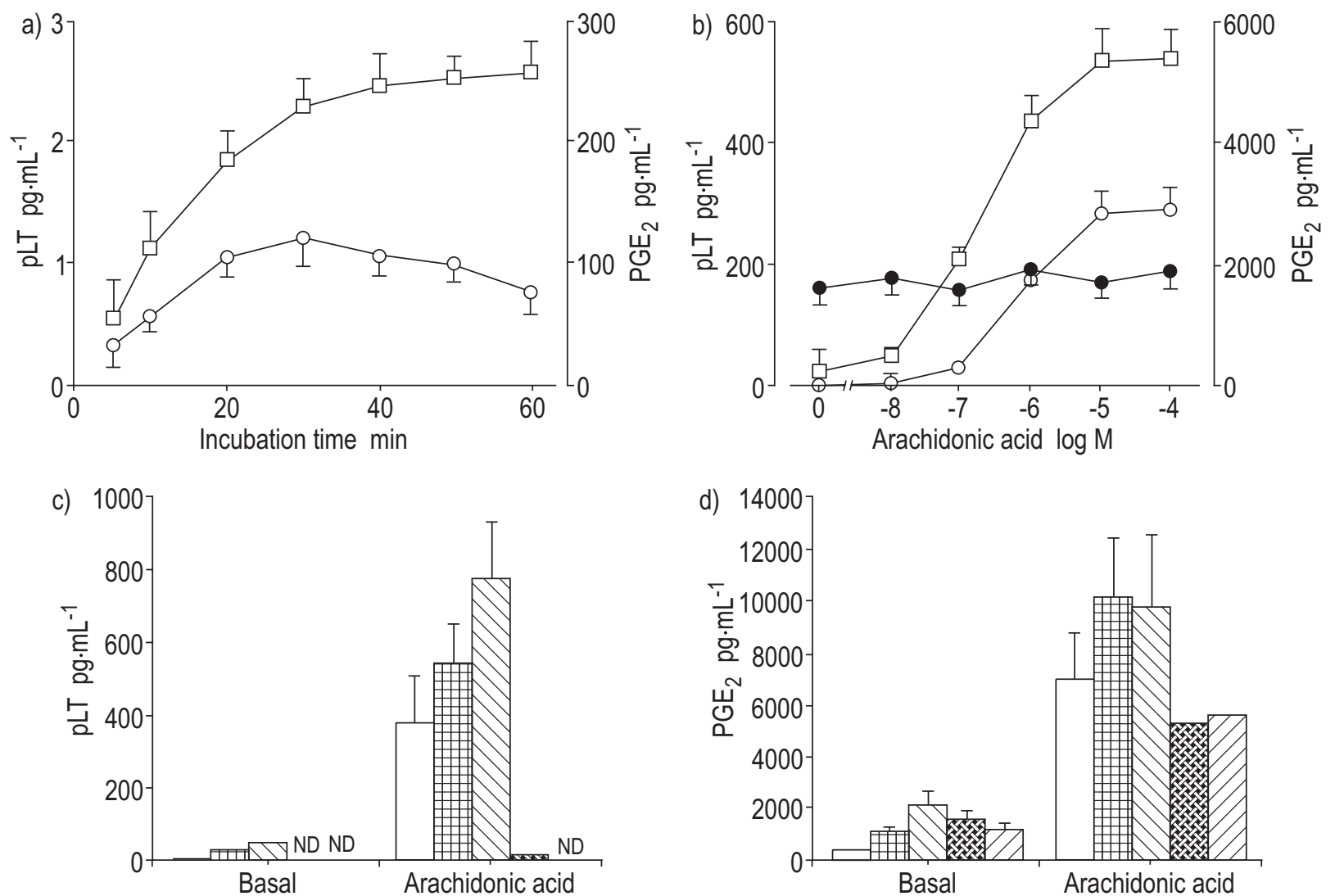

Fig. 1. - a) Kinetics of basal eicosanoid (peptidoleukotriene (pLT; $\bigcirc)$ and prostaglandin $\mathrm{E}_{2}\left(\mathrm{PGE}_{2}\right.$; $\square$ )) release. In this experiment $10^{5}$ peripheral blood cells $(\mathrm{PBC}) \cdot \mathrm{mL}^{-1}$ from normal subjects $(\mathrm{n}=7)$ were incubated in duplicates. b) Dose response to arachidonic acid. In this experiment $10^{5} \mathrm{PBC}^{\mathrm{mL}} \mathrm{mL}^{-1}$ from normal subjects $(\mathrm{n}=10)$ were incubated in duplicates. $\bullet$ : histamine (His). c) pLT release from different cell types. In experiments for both (c) and (d) cells were separated from normal subjects $(n=10)$ by Ficoll gradient centrifugation. Every cell subset $(\square$ : PBC; 曲: monocytes; $\mathbb{Q}$ : polymorphonuclear granulocytes; : T-lymphocytes; $\mathbb{Z}$ : Jurkat human T-cell line) was standardized to $10^{5}$ cells $\cdot \mathrm{mL}^{-1}$. Samples were incubated in duplicates. ND: No detectable levels found. Bars indicate SEM. 

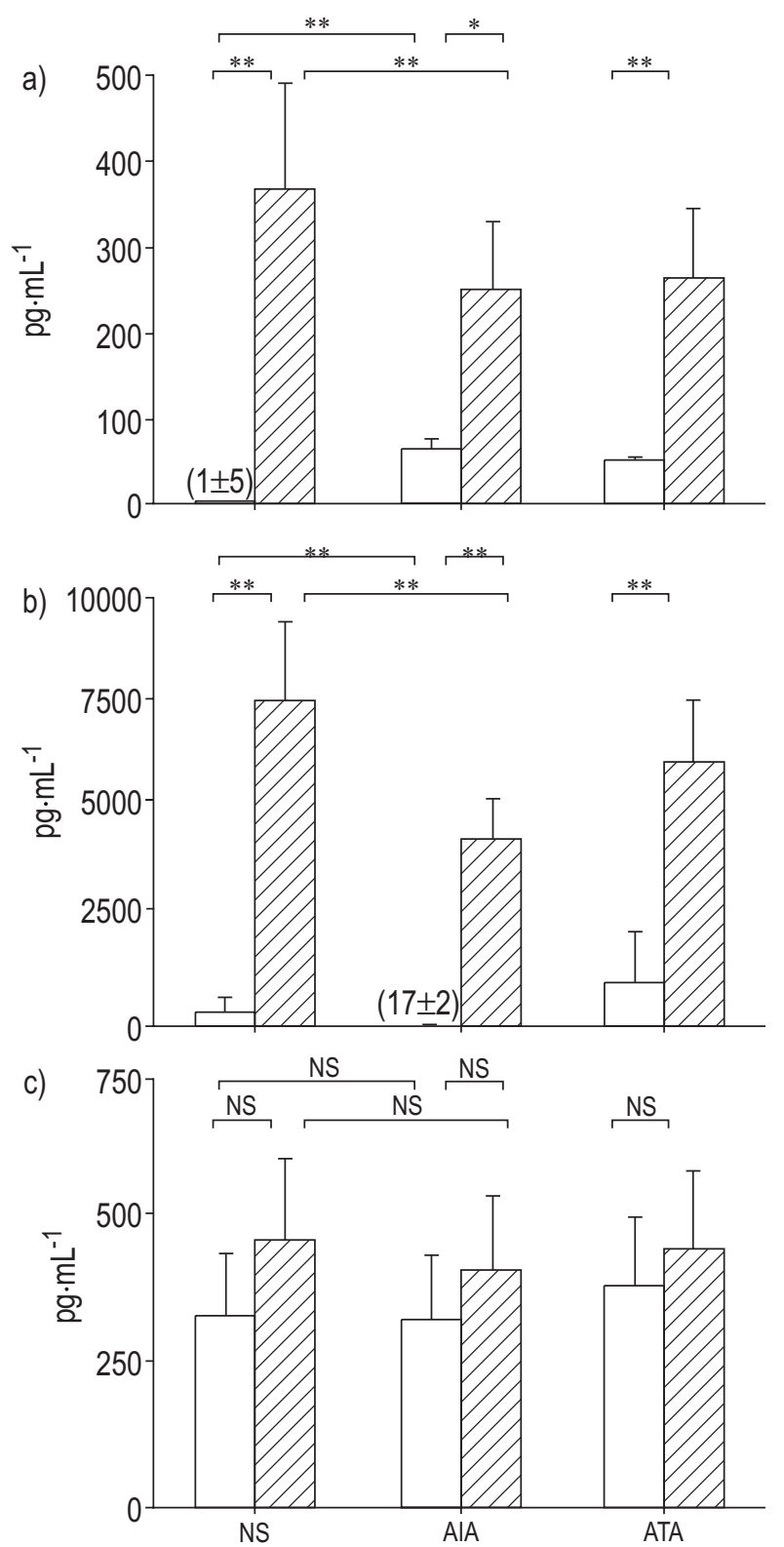

Fig. 2. - Induced mediator release of peptidoleukotriene (a), prostaglandin $\mathrm{E}_{2}(\mathrm{~b})$ and histamine (c). Basal $(\square)$ and arachidonic acid (Z)induced $\left(10^{-5} \mathrm{M}\right)$ eicosanoid and histamine release were measured in duplicate samples of peripheral blood cells from aspirin-intolerant asthmatics (AIA; $n=10$ ), aspirin-tolerant asthmatics (ATA; $n=8)$ and normal subjects $(\mathrm{NS} ; \mathrm{n}=10)$ before aspirin challenge. Numerical values in parentheses have been added where bars are not clearly visible. *: $\mathrm{p}<0.05 ; * *: \mathrm{p}<0.01$.

\section{Results}

Eicosanoid release: kinetic, arachidonic acid induced release and involved cell type

The kinetic of basal $\mathrm{pLT}$ and $\mathrm{PGE}_{2}$ release of $\mathrm{PBC}$ from normal subjects are shown in figure 1a. Basal pLT release was at a maximum after $20 \mathrm{~min}$ of incubation $(1.2 \pm 0.8$ $\left.\mathrm{pg} \cdot \mathrm{mL}^{-1}\right)$ and decreased after that $\left(0.8 \pm 0.3 \mathrm{pg} \cdot \mathrm{mL}^{-1}\right.$ after $60 \mathrm{~min})$, whereas basal $\mathrm{PGE}_{2}$ release had a slower onset $\left(185 \pm 31.5 \mathrm{pg} \cdot \mathrm{mL}^{-1}\right.$ after $\left.20 \mathrm{~min}\right)$ and without a significant decrease during the observed incubation time $(258 \pm 49.1$ $\mathrm{pg} \cdot \mathrm{mL}^{-1}$ after $60 \mathrm{~min}$ ) in this protocol. Optimal detection levels for both eicosanoids were achieved after $20 \mathrm{~min}$ of incubation with $10^{5} \mathrm{PBC} \cdot \mathrm{mL}^{-1}$. Similar results were obtained by stimulation with arachidonic acid $\left(10^{-5} \mathrm{M}\right.$, data not shown). The production of pLT was more than ten times lower than for $\mathrm{PGE}_{2}$ release.

For arachidonic acid a concentration dependent elevation of $\mathrm{pLT}$ and $\mathrm{PGE}_{2}$ release was measured, using $20 \mathrm{~min}$ of incubation with $10^{5} \mathrm{PBC} \cdot \mathrm{mL}^{-1}$ (fig. 1b). Again after stimulation with $10^{-5} \mathrm{M}$ arachidonic acid, where mediator release reached stable levels, pLT release was lower $(282 \pm$ $\left.45.7 \mathrm{pg} \cdot \mathrm{mL}^{-1}\right)$ than $\mathrm{PGE}_{2}$ release $\left(5,240 \pm 354.6 \mathrm{pg} \cdot \mathrm{mL}^{-1}\right)$. This concentration of arachidonic acid was selected for further study. Histamine release of PBC $(181.2 \pm 23.4 \mathrm{pg}$. $\mathrm{mL}^{-1}$ ) was not influenced by stimulation with exogenous arachidonic acid.

As seen in figure 1c, basal and arachidonic acid-induced pLT and $\mathrm{PGE}_{2}$ release of PBC (basal pLT: $1.2 \pm 0.6$ $\mathrm{pg} \cdot \mathrm{mL}^{-1}$, induced $\mathrm{pLT}$ : $378 \pm 47.2 \mathrm{pg} \cdot \mathrm{mL}^{-1}$; basal $\mathrm{PGE}_{2}$ : $380 \pm 26.1 \mathrm{pg} \cdot \mathrm{mL}^{-1}$, induced $\mathrm{PGE}_{2}: 7,050 \pm 1,540 \mathrm{pg} \cdot \mathrm{mL}^{-1}$ ) can be attributed mostly to monocytes (basal pLT $23 \pm 9.6$ $\mathrm{pg} \cdot \mathrm{mL}^{-1}$, induced pLT $543 \pm 154.3 \mathrm{pg} \cdot \mathrm{mL}^{-1}$; basal $\mathrm{PGE}_{2}$ : $1,080 \pm 97.5 \mathrm{pg} \cdot \mathrm{mL}^{-1}$, inducedPGE $2: 10,200 \pm 2,430 \mathrm{pg} \cdot \mathrm{mL}^{-1}$ ) and polymorphonuclear granulocytes (basal pLT $45 \pm$ $12.4 \mathrm{pg} \cdot \mathrm{mL}^{-1}$, induced $\mathrm{pLT} 777.6 \pm 194.7 \mathrm{pg} \cdot \mathrm{mL}^{-1}$; basal $\mathrm{PGE}_{2}: 2,910 \pm 341.5 \mathrm{pg} \cdot \mathrm{mL}^{-1}$, induced $\mathrm{PGE}_{2}: 9,780 \pm 2,610$ $\mathrm{pg} \cdot \mathrm{mL}^{-1}$ ), which are part of PBC used in the other experiments. The Jurkat T-cell line did not release pLT, but $\mathrm{PGE}_{2}$ (basal 1,560 $\pm 150.7 \mathrm{pg} \cdot \mathrm{mL}^{-1}$, induced 5,340 \pm 395.2 $\mathrm{pg} \cdot \mathrm{mL}^{-1}$ ) in this procedure. Also for the separated T-cells no amounts of basal pLT release were measured. But there were minute amounts after stimulation with arachidonic acid $\left(10 \pm 7.1 \mathrm{pg} \cdot \mathrm{mL}^{-1}\right)$, which can be explained by the separation technique and a contamination with monocytes/ granulocytes of $2 \%$. $\mathrm{PGE}_{2}$ release of separated T-lymphycytes was similar to that of the Jurkat T-cell line (basal $1,160 \pm 134.1 \mathrm{pg} \cdot \mathrm{mL}^{-1}$, induced $\left.5,660 \pm 428.6 \mathrm{pg} \cdot \mathrm{mL}^{-1}\right)$. The data shown supports the idea that the examination of PBC could be a valuable method to analyse basics of eicosanoid metabolism and to develop a screening test for aspirin intolerance.

\section{Induction of eicosanoid release before aspirin chal-} lenge

Testing the synthesis capacity of 5-lipoxygenase and cyclooxygenase and getting around $\mathrm{PLA}_{2}$-dependent mechanisms, PBC were incubated with arachidonic acid. As shown in figure 2 , pLT and $\mathrm{PGE}_{2}$ release were significantly elevated by addition of arachidonic acid with no effect on histamine release in normal subjects, AIAs or ATAs. PBC of AIAs released significantly higher levels of basal pLT $\left(55.5 \pm 8.5 \mathrm{pg} \cdot \mathrm{mL}^{-1}\right)$ but significantly lower basal $\mathrm{PGE}_{2}\left(17 \pm 9.7 \mathrm{pg} \cdot \mathrm{mL}^{-1}\right)$ than the normal subjects $\left(1.5 \pm 0.4 \mathrm{pg} \cdot \mathrm{mL}^{-1}\right.$ for $\mathrm{pLT}$ and $236 \pm 38.2 \mathrm{pg} \cdot \mathrm{mL}^{-1}$ for $\left.\mathrm{PGE}_{2}\right)$. ATAs released similar amounts of basal pLT $(40.2 \pm 9.6$ $\left.\mathrm{pg} \cdot \mathrm{mL}^{-1}\right)$ as AIAs, but in contrast to AIAs a huge release of basal $\mathrm{PGE}_{2}\left(723.8 \pm 69.3 \mathrm{pg} \cdot \mathrm{mL}^{-1}\right)$ was noted. Although basal $\mathrm{PGE}_{2}$ release in AIAs was extremely low $(17 \pm 9.7$ $\left.\mathrm{pg} \cdot \mathrm{mL}^{-1}\right)$ it could be stimulated very well by arachidonic acid (by a factor of 235). Arachidonic acid-induced $\mathrm{PGE}_{2}$ release did not differ significantly in all groups $(7,378 \pm$ $1,530 \mathrm{pg} \cdot \mathrm{mL}^{-1}$ for normal subjects, $4,099 \pm 958 \mathrm{pg} \cdot \mathrm{mL}^{-1}$ 


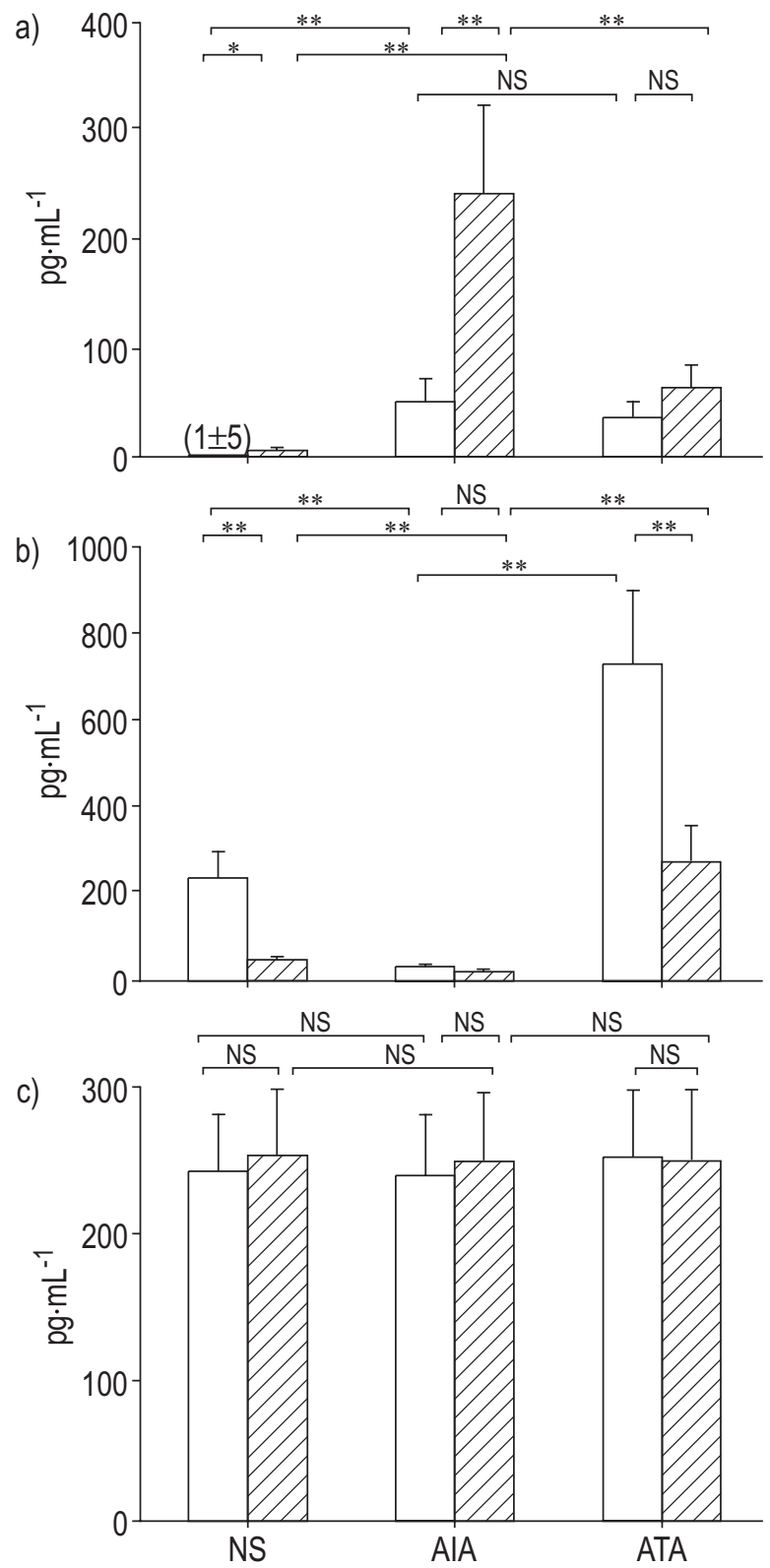

Fig. 3. - Basal mediator release influenced by aspirin challenge. Basal release of peptidoleukotriene (a), prostaglandin $\mathrm{E}_{2}$ (b) and histamine (c) of peripheral blood cells was quantified before and after aspirin challenge in normal subjects $(\mathrm{NS} ; \mathrm{n}=10)$ and aspirin-intolerant asthmatics (AIA; $n=10$ ) and aspirin-tolerant asthmatics (ATA; $n=8$ ) in duplicate samples. $\square$ : before challenge; $\mathbb{Z}$ : after challenge. Numerical values in parentheses have been added where bars are not clearly visible. $*: \mathrm{p}<0.05 ; * *: \mathrm{p}<0.01$. for AIAs, and $5,800 \pm 1,080 \mathrm{pg} \cdot \mathrm{mL}^{-1}$ for ATAs). Furthermore, the pLT release was stimulated by arachidonic acid to a smaller extent in AIAs (by a factor of 4.2) and ATAs (by a factor of 6.1), than in the control group (by a factor of 360). There was no significant differen- ces in basal $\left(241.2 \pm 31.6 \mathrm{pg} \cdot \mathrm{mL}^{-1}\right.$ for AIAs, $253.4 \pm 24.6 \mathrm{pg} \cdot \mathrm{mL}^{-1}$ for ATAs, and $241.9 \pm 39.7 \mathrm{pg} \cdot \mathrm{mL}^{-1}$ for normal subjects) and arachidonic acid-induced $\left(282 \pm 51.4 \mathrm{pg} \cdot \mathrm{mL}^{-1}\right.$ for AIAs, $312 \pm 92.3 \mathrm{pg} \cdot \mathrm{mL}^{-1}$ for ATAs, and $241.9 \pm 19.1 \mathrm{pg} \cdot \mathrm{mL}^{-1}$ for normal subjects) histamine release between all groups. As expected stimulation with arachidonic acid did not influence histamine release.

Basal mediator release before and after aspirin challenge

The in vivo effect of lysine-aspirin on basal mediator release was investigated in vitro. Before aspirin provocation there was highly elevated basal pLT release in AIAs $\left(55.5 \pm 8.5 \mathrm{pg} \cdot \mathrm{mL}^{-1}\right)$ and ATAs $\left(40.2 \pm 9.6 \mathrm{pg} \cdot \mathrm{mL}^{-1}\right)$, whereas in healthy controls the initial levels were low $(1.5 \pm 0.4$ $\left.\mathrm{pg} \cdot \mathrm{mL}^{-1}\right)$. After aspirin provocation there was a significant increase of pLT release in AIAs $\left(237.4 \pm 34.8 \mathrm{pg} \cdot \mathrm{mL}^{-1}\right)$. In contrast, in ATAs, the increase of pLT release was not statistically significant $\left(64.7 \pm 25.3 \mathrm{pg} \cdot \mathrm{mL}^{-1}\right)$ and in healthy controls the increase was minimal $\left(7.5 \pm 1.6 \mathrm{pg} \cdot \mathrm{mL}^{-1}\right)$. The basal $\mathrm{PGE}_{2}$ release before aspirin challenge in AIAs (17 \pm $\left.9.7 \mathrm{pg} \cdot \mathrm{mL}^{-1}\right)$ was significantly lower than in normal subjects $\left(236 \pm 38.2 \mathrm{pg} \cdot \mathrm{mL}^{-1}\right)$ and ATAs $\left(723.8 \pm 69.3 \mathrm{pg} \cdot \mathrm{mL}^{-1}\right)$. After challenge, no significant change of $\mathrm{PGE}_{2}$ release was measured in PBC from AIAs $\left(20 \pm 8.9 \mathrm{pg} \cdot \mathrm{mL}^{-1}\right)$, but a significant decrease of $\mathrm{PGE}_{2}$ release in PBC from ATAs $\left(268.7 \pm 57.3 \mathrm{pg} \cdot \mathrm{mL}^{-1}\right)$ and normal subjects $(40 \pm 11.2 \mathrm{pg}$. $\mathrm{mL}^{-1}$ ) was found. No changes were observed on histamine release before or after lysine-aspirin challenge in AIAs $\left(241.2 \pm 31.6 \mathrm{pg} \cdot \mathrm{mL}^{-1}\right.$ before and $247.3 \pm 22.4 \mathrm{pg} \cdot \mathrm{mL}^{-1}$ after challenge), ATAs $\left(253.4 \pm 24.6 \mathrm{pg} \cdot \mathrm{mL}^{-1}\right.$ before and $249.5 \pm$ $27.2 \mathrm{pg} \cdot \mathrm{mL}^{-1}$ after challenge) and normal subjects $(241.9 \pm$ $19.1 \mathrm{pg} \cdot \mathrm{mL}^{-1}$ before and $251.1 \pm 23.9 \mathrm{pg} \cdot \mathrm{mL}^{-1}$ after challenge) (fig. 3). Major eicosanoid release data including arachidonic acid-induced release and data before and after in vivo lysine-aspirin challenge are summarized in table 1.

The role of $\mathrm{PGE}_{2}$ and histamine before and during the in vivo action of inhaled lysine-aspirin in all AIAs was investigated in more detail. Increasing doses of inhaled lysine-aspirin reduced the basal $\mathrm{PGE}_{2}$ release and histamine release was unaffected by provocation. The relationship of basal $\mathrm{PGE}_{2}$ release and change of FEV1 is shown in figure $4 \mathrm{a}$. The threshold aspirin dose correlated well with the biggest change in $\mathrm{FEV} 1 . \mathrm{PGE}_{2}$ release correlated inversely with FEV1 $(\mathrm{r}=0.87$, fig. $4 \mathrm{~b}$ and table 2$)$.

Table 1. - Summary of major eicosanoid release data

\begin{tabular}{|c|c|c|c|c|c|c|c|}
\hline \multirow{2}{*}{ Mediator } & \multirow{2}{*}{ Challenge } & \multicolumn{2}{|c|}{ NS } & \multicolumn{2}{|c|}{ AIA } & \multicolumn{2}{|c|}{ ATA } \\
\hline & & B & AA & B & AA & B & AA \\
\hline \multirow[t]{2}{*}{$\mathrm{PGE}_{2}$} & Before & $236 \pm 38.2$ & $7378 \pm 1530$ & $20 \pm 9.7$ & $4534 \pm 82.1$ & $723 \pm 69.3$ & $5800 \pm 361$ \\
\hline & After & $40 \pm 11.2$ & $3793 \pm 1756$ & $17 \pm 8.9$ & $4089 \pm 95.8$ & $268 \pm 57.3$ & $3963 \pm 1132$ \\
\hline \multirow[t]{2}{*}{$\mathrm{pLT}$} & Before & $1.5 \pm 0.4$ & $540 \pm 91.1$ & $55.5 \pm 8.5$ & $233 \pm 31.4$ & $40.2 \pm 9.6$ & $245 \pm 41.5$ \\
\hline & After & $7.5 \pm 1.6$ & $724 \pm 174.4$ & $237 \pm 34.8$ & $581 \pm 149$ & $64.7 \pm 25.3$ & $623 \pm 153$ \\
\hline
\end{tabular}

Data presented as $\mathrm{pg} \cdot \mathrm{mL}^{-1}$. B: basal eicosanoid release; AA: arachidonic acid-induced eicosanoid release; Before: eicosanoid release before in vivo challenge with lysine-aspirin; After: eicosanoid release after in vivo challenge with lysine-aspirin; NS: normal subjects; AIA: aspirin-intolerant asthmatics; ATA: aspirin-tolerant asthmatics; $\mathrm{PGE}_{2}$ : prostaglandin-E $\mathrm{E}_{2}$; pLT: peptide leukotriene. 

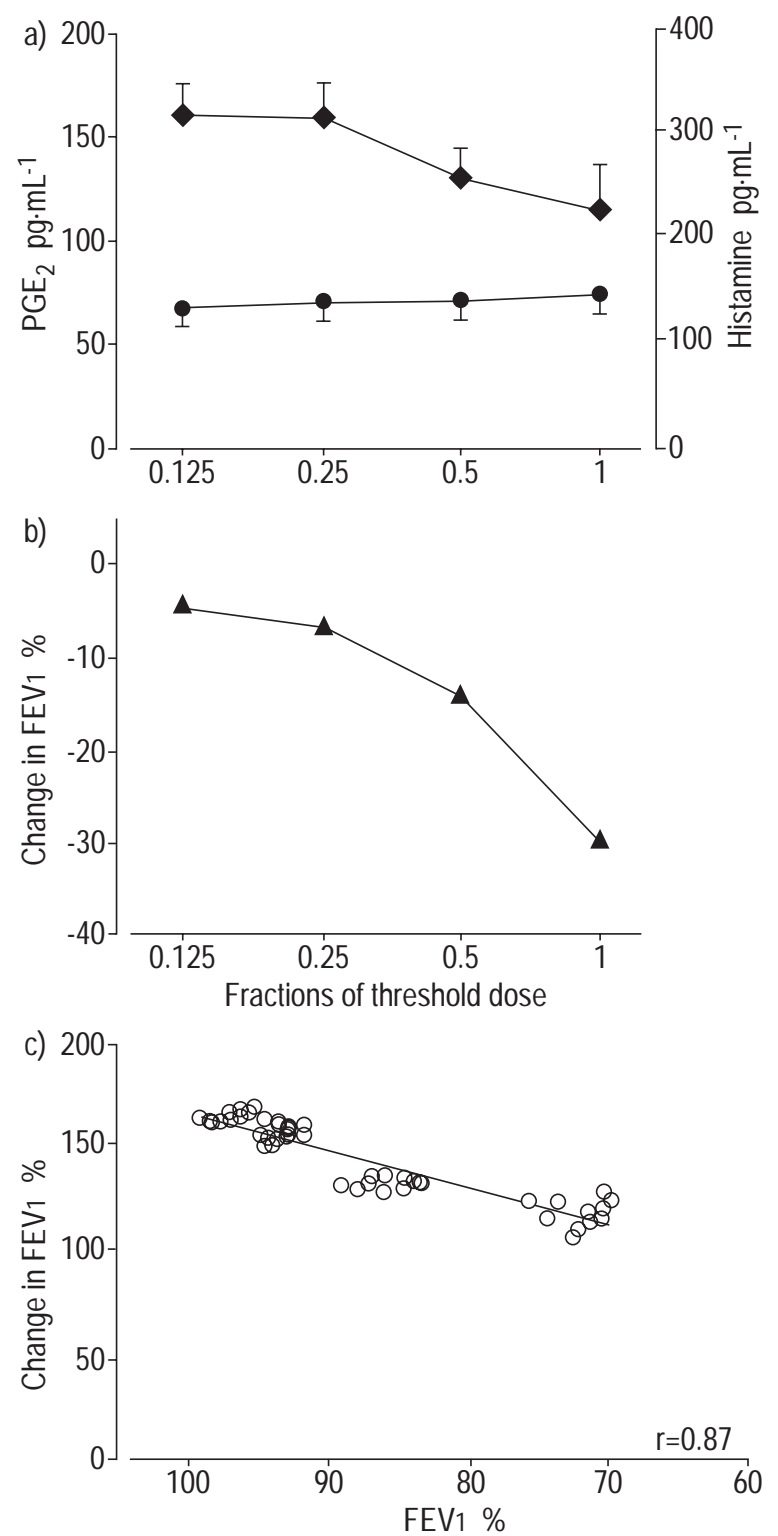

Fig. 4. - Effects of bronchial provocation and desensitization on mediator release $(a$ and $b)$. The relation of forced expiratory volume in one second $(\mathrm{FEV} 1 ; \boldsymbol{\Delta})$ values and $(\mathrm{b})$ prostaglandin $\mathrm{E}_{2}\left(\mathrm{PGE}_{2} ; \bullet\right)$ and histamine (๑) release (a) are shown for all aspirin-intolerant asthmatics (AIA; $n=10)$. As the threshold dose was individually different the applied dose of aspirin is shown as fractions/multiples of the threshold dose. There was no significant change in basal histamine release during provocation and desensitization. The significant fall of $\mathrm{PGE}_{2}$ correlated with FEV1. During inhalative provocation the time between each step of challenge was $30 \mathrm{~min}$. The bars indicate SEM. The correlation of FEV1 and $\mathrm{PGE}_{2}$ is also shown (c), where four measurements of FEV1 and $\mathrm{PGE}_{2}$ release for each patient $(n=10)$ were made.

\section{Effect of $P G E_{2}$ on pLT release}

To elucidate the interaction of $\mathrm{PGE}_{2}$ and $\mathrm{pLT}$, the effect of $\mathrm{PGE}_{2}$ on pLT release was investigated. Therefore, $\mathrm{PBC}$ were preincubated with various concentrations $\left(10^{-8}-10^{-5}\right.$ M) of $\mathrm{PGE}_{2}$, dibutyryl-cAMP or the 5-lipoxygenase inhibitor caffeic acid [24]. In normal subjects, $\mathrm{PGE}_{2}$ reduced $\mathrm{pLT}$ release in a dose-dependent fashion with $78 \%$ inhibition of arachidonic acid-induced pLT release at $10^{-5}$ $\mathrm{M} \mathrm{PGE}_{2}$. Similar results were obtained by preincubation of
Table 2. - Individual values of forced expiratory volume in one second (FEV 1 ) during bronchial provocation in aspirin intolerant asthmatics

\begin{tabular}{lcc}
\hline $\begin{array}{l}\text { Patient } \\
\text { No. }\end{array}$ & $\begin{array}{c}\text { Cumulative dose of } \\
\text { aspirin } \\
\text { mg }\end{array}$ & $\begin{array}{c}\text { Decrease of FEV1 after } \\
\text { provocation } \\
\%\end{array}$ \\
\hline 1 & 63.75 & 18 \\
2 & 63.75 & 21 \\
3 & 38.25 & 28 \\
4 & 8.75 & 65 \\
5 & 16.25 & 49 \\
6 & 63.75 & 20 \\
7 & 38.25 & 27 \\
8 & 8.75 & 56 \\
9 & 3.75 & 62 \\
10 & 16.25 & 27 \\
\hline
\end{tabular}

The FEV1 was measured in triplicates. The individual decrease of FEV1 was calculated using the individual FEV1 value before and after inhalative bronchial provocation with lysin-aspirin. Bronchial provocation was performed as described in Materials and methods. In all the other groups (aspirin-tolerant asthmamatics and normal subjects) there was no statistically decrease of FEV1 measured after oral provocation with $500 \mathrm{mg}$ of aspirin.

PBC with the membrane-penetrating analogue of cAMP, dibutyryl-cAMP (74\% inhibition, $\mathrm{p}<0.01)$, and caffeic acid (67\% inhibition, $\mathrm{p}<0.01)$. The inhibition was stronger on PBC from control subjects than from AIAs. The inhibitory effect on PBC from ATAs was greater compared to AIAs but slightly less than in normal subjects. These data support the hypothesis of a cAMP-dependent mechanism of action of $\mathrm{PGE}_{2}$ (fig. 5a-c).

\section{$\mathrm{PGE}_{2} / p L T$ relation in AIAs and control subjects}

Another point of interest was the relation of $\mathrm{PGE}_{2}$ and pLT release because of the inhibitory effect of $\mathrm{PGE}_{2}$ as shown before. Therefore, basal release $\mathrm{PGE}_{2}$ values were related to basal pLT values from AIAs, ATAs and normal subjects using the data described in figure 3 . The results given in figure 6 , clearly demonstrate differences with a very low $\mathrm{PGE}_{2} / \mathrm{pLT}$ relation in AIAs before and even after lysine-aspirin challenge (before 0.8 , after 0.3 ) whereas the healthy control subjects had a high $\mathrm{PGE}_{2} / \mathrm{pLT}$ relation before (280) and a low relation after aspirin challenge (9.8). Before aspirin challenge ATAs had similar elevated pLT levels as AIAs which were compensated by excessive release of $\mathrm{PGE}_{2}$. This resulted in a higher $\mathrm{PGE}_{2} / \mathrm{pLT}$ relation before challenge (15.2) than in AIAs and a still positive $\mathrm{PGE}_{2} / \mathrm{pLT}$ relation after challenge (4.8) which was similar to control subjects.

\section{Discussion}

In this study, the arachidonic acid metabolism and histamine release of PBC from AIAs, ATAs and healthy controls were investigated with respect to bronchoconstrictive pLT [5] and bronchoprotective $\mathrm{PGE}_{2}[4,16]$ before and after aspirin challenge. The underlying mechanisms of bronchoconstriction in AIAs are not known, but 

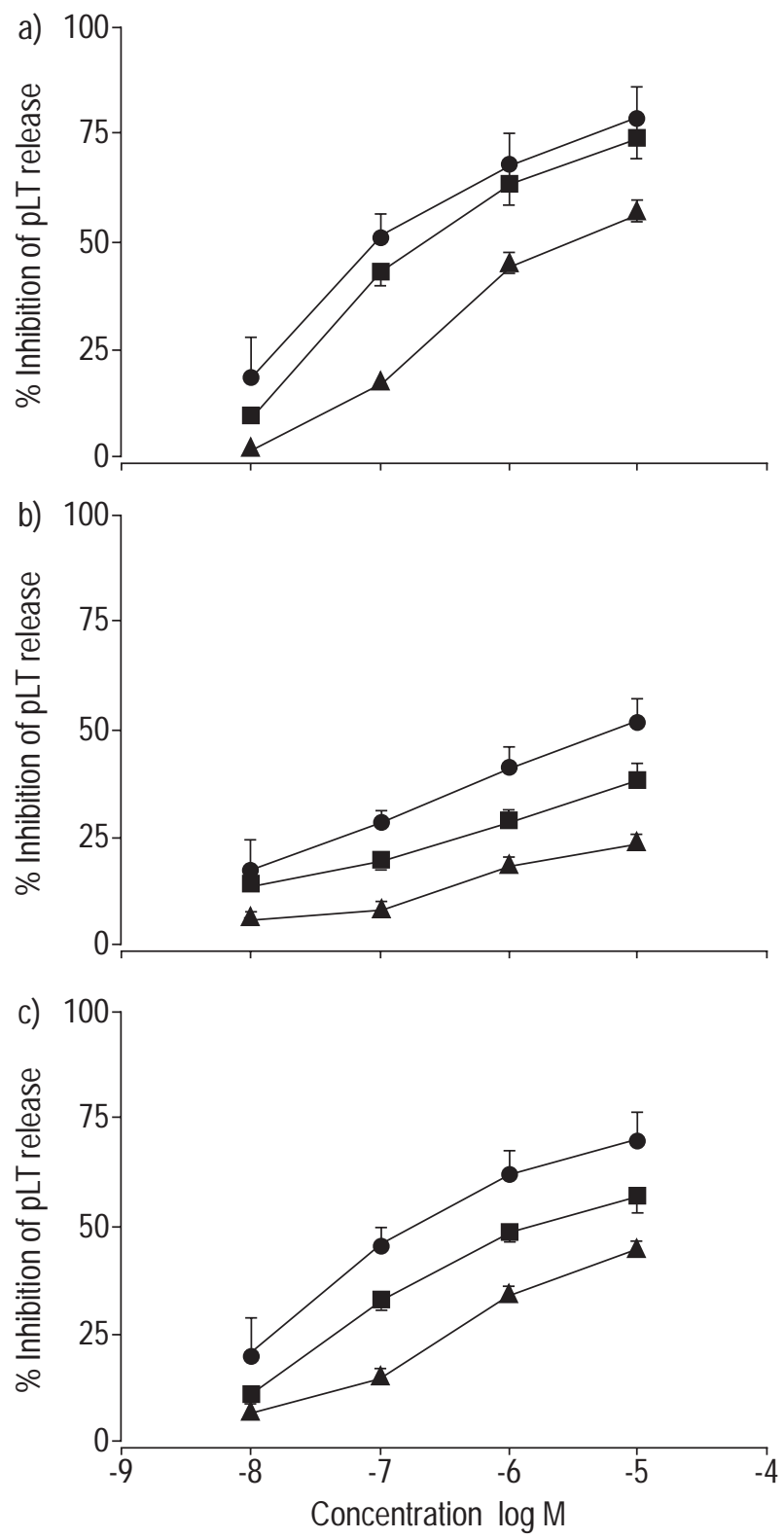

Fig. 5. - Effect of prostaglandin $\mathrm{E}_{2}\left(\mathrm{PGE}_{2}\right)$ on peptidoleukotriene (pLT) release. a) Inhibition of pLT release in peripheral blood cells (PBC) from normal subjects; b) inhibition of pLT release in PBC from aspirinintolerant asthmatics (AIAs); c) inhibition of pLT release in PBC from aspirin-tolerant asthmatics (ATAs). PBC from normal subjects $(n=10)$, AIAs $(n=10)$ and ATAs $(n=8)$ were preincubated for 15 min with variable concentrations of $\mathrm{PGE}_{2}(\bullet)$, dibuteryl-cyclic adenosine monophosphate $(\boldsymbol{\square})$ or the 5-lipoxygenase inhibitor caffeic acid $(\boldsymbol{\Delta})$. Thereafter, PBC were incubated with arachidonic acid $\left(10^{-5} \mathrm{M}\right)$ for another $20 \mathrm{~min}$. Samples were performed in duplicates and the bars indicate SEM.

the hypothesis of an altered metabolism of arachidonic acid metabolism is generally accepted [4, 6-18].

For the first time comparative measurements of pLT, $\mathrm{PGE}_{2}$ and histamine in PBC of AIAs were performed, using a "functional cell test" which allowed transcellular metabolism as well as complex interactions of mediators [25]. An optimum of eicosanoid release could be found after $20 \mathrm{~min}$, which corresponds well to previous studies $[13,25]$. In a former study with monocytes, which focused on thromboxane- $\mathrm{B}_{2}$ and $\mathrm{LTB}_{4}$ release [13], the blood was

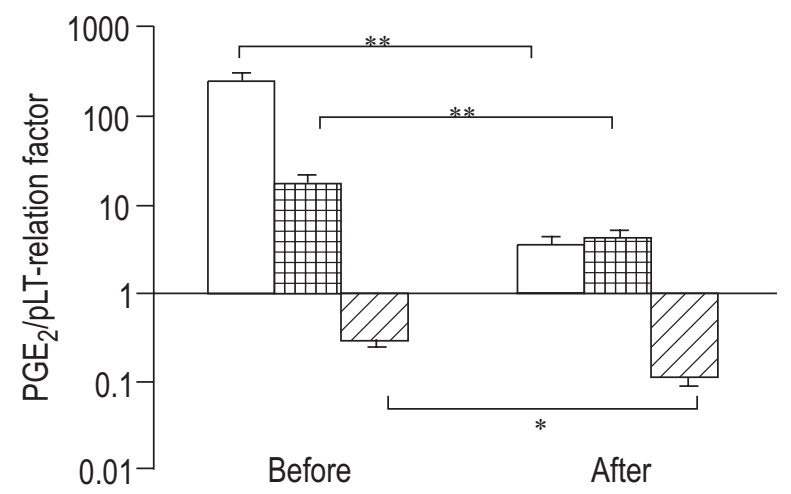

Fig. 6. - Relation of prostaglandin $\mathrm{E}_{2}\left(\mathrm{PGE}_{2}\right)$ and peptidoleukotriene (pLT) release. The quotient for basal release of $\mathrm{PGE}_{2}$ and pLT was calculated in normal subjects $(\square ; n=10)$, in aspirin-intolerant asthmatics $(\mathbb{Z} ; n=10)$ and aspirin-tolerant asthmatics $($ 曲; $n=8)$. This was performed for values before and after aspirin challenge. $*$ : $\mathrm{p}<0.05 ; * *$ : $<<0.01$. Bars indicate SEM.

collected in syringes containing the calcium chelator ethylenediamine tetraacetic acid (EDTA) and the cells were stimulated with the calcium ionophore A23187 in a calcium reconstituted medium; furthermore these patients received topical and/or systemic corticosteroids. In contrast to that study, the "functional cell test" could demonstrate significant differences in basal pLT release and a significant increase of all eicosanoids after stimulation with the arachidonic acid. This can be explained by the design of the "functional cell test" using PBC from patients without relevant corticosteroid therapy and a preparation technique not affecting the calcium and corticosteroid sensitivity $[21,26]$ of enzymes. In addition the "functional cell test" allows naturally occurring multicellular interactions [25]. The concentration-dependent inhibition of pLT release by $\mathrm{PGE}_{2}$ was most likely caused by an increase of intracellular cAMP (fig. 5), which was shown before in neutrophil leukocytes for chemotactically active $\mathrm{LTB}_{4}$ [27]. The inhibition of arachidonic acid-induced pLT release by $\mathrm{PGE}_{2}$ was more potent on a molar basis than the specific 5-lipoxygenase inhibitor caffeic acid. Lower sensitivity of PBC from AIAs to $\mathrm{PGE}_{2}$ (fig. 5) might be caused by downregulation or diminished binding to PGE receptor subtypes $\left(\mathrm{EP}_{\mathrm{x}}\right)$, reduced availability of endogenous $\mathrm{PGE}_{2}$ or by elevated cAMP degradation.

Before lysine-aspirin challenge, basal release of pLT was significantly higher in AIAs and ATAs than in healthy controls. This confirms previous measurements of increased urinary $\mathrm{pLT}$, which reflect the whole leukotrienemetabolism of the body [9-11] and studies of bronchial [6] or nasal $[7,8]$ lavage fluids. The "functional cell test" presented here, demonstrated a vastly reduced basal release of $\mathrm{PGE}_{2}$ in $\mathrm{PBC}$ of AIAs. These results underline the importance of measuring eicosanoid release in intact cells, as previous studies could not find any difference of $\mathrm{PGE}_{2}$ levels in blood serum [17]. $\mathrm{PGE}_{2}$ release in $\mathrm{PBC}$ from AIAs could be stimulated very well, but could not reach the level of stimulated release in controls (fig. 2). These results are in contrast to former reports focusing on platelet function [12].

The most striking difference occurred in basal $\mathrm{PGE}_{2}$ release comparing AIAs with ATAs and normal subjects before aspirin challenge. On the one hand there was an unexpected reduced basal $\mathrm{PGE}_{2}$ release from AIAs in 
contrast to the higher levels of $\mathrm{PGE}_{2}$ in ATAs and normal subjects. On the other hand $\mathrm{PGE}_{2}$ release in AIAs could be stimulated very well with exogenous arachidonic acid. There was no significant difference between all three groups tested. There are three possible interpretations for this phenomenon. Firstly, in AIAs there might be reduced availability of arachidonic acid presumably via diminished release of arachidonic acid from phospholipid membranes. Secondly, a lowered affinity of cyclooxygenases to arachidonic acid in AIAs, and finally decreased basal metabolic activity of cyclooxygenases. Regarding the other possible pathway of arachidonic acid metabolism, both, AIAs and ATAs showed similar highly elevated basal pLT release.

After bronchial challenge, there was a massive increase of already elevated basal pLT in AIAs but not in ATAs and normal subjects. The latter showed only a slight increase of pLT release. These findings support the "shunting theory" of arachidonic acid metabolism [13]. "Shunting" seems to be more typical for AIAs than for ATAs investigated in this study. The prior decrease of $\mathrm{PGE}_{2}$ release during lysineaspirin challenge, which was pharmacologically expected, correlated with a time shifted decrease in FEV1 $(r=0.87$, fig. 4b) but was not associated with changes in histamine release (figs. 2 and 3). This leads to the assumption that histamine is not involved in an asthma attack of AIAs and again pointed to the role of $\mathrm{PGE}_{2}$. After in vivo lysineaspirin challenge there was a different response of basal $\mathrm{PGE}_{2}$ and $\mathrm{pLT}$ release in each group. After stimulation with exogenous arachidonic acid it was surprising to find no significant difference of eicosanoid release between AIAs, ATAs and normal subjects (fig. 3 and table 1).

Combining the role of reduced basal $\mathrm{PGE}_{2}$ release in AIAs as discussed above and similar arachidonic acidinduced eicosanoid release after aspirin challenge in all three groups (AIAs, ATAs, normal subjects) might lead to the following explanation. It is known that exogenous arachidonic acid in human cells is incorporated into cytoplasmic "lipid bodies" [28]. These lipid bodies are surrounded by cyclooxygenase, which is not membranebound and could not yet be differentiated into the two isoenzymes of cyclooxygenase [29]. The lack of response of the AIAs to exogenous arachidonic acid on $\mathrm{PGE}_{2}$ production might be due to the following. 1) Lack of endogenous substrate (arachidonic acid) in AIAs by insufficient formation of lipid bodies; only if there is a surplus of exogenous arachidonic acid, $\mathrm{PGE}_{2}$ will be synthesized in sufficient quantities, as it was demonstrated here for ATAs and normal subjects. 2) Defect of the cyclooxygenase with higher metabolic activity in AIAs; as two isoenzymes are known [4, 15, 25, 29]; also a different sensitivity of cyclooxygenases towards aspirin is assumed [30]. This would explain the finding that there was no significant change of arachidonic acid-induced $\mathrm{PGE}_{2}$ release after in vivo aspirin exposure in AIAs but a significant reduction in ATAs and healthy controls.

Summarizing the results, there is a typical "profile" of eicosanoids in the AIAs, ATAs and normal subjects, which might be brought into line with current theories of pathogenesis $[4,13,14,16]$. It was concluded that the reduced basal $\mathrm{PGE}_{2}$ release in AIAs plays a key role, as the lack of $\mathrm{PGE}_{2}$ and consequent loss of endogenous inhibition of 5-lipoxygenase leads to an increase of basal pLT. This might be of interest in developing new, more effective strategies in the drug therapy of aspirin-induced asthma, i.e. combined drugs of $\mathrm{PGE}_{2}$ and 5-lipoxygenase inhibitors or leukotriene-receptor antagonists. The bronchoprotective effect of inhaled $\mathrm{PGE}_{2}[4,16]$ is most likely mediated by direct inhibition of pLT release as it has been recently reported for human bronchial biopsy specimens [24]. When AIAs are challenged with aspirin, pLT release increases most likely because of further reduction of inhibitory $\mathrm{PGE}_{2}$ and/or partially by "shunting" of arachidonic acid metabolism and/or release of other bronchoconstrictive mediators. This becomes clinically evident as an asthma attack in AIAs, whereas in ATAs a surplus of $\mathrm{PGE}_{2}$ before challenge can possibly prevent a reduction of $\mathrm{PGE}_{2}$ under a critical threshold after aspirin ingestion. This also might provide some evidence for the protective properties of $\mathrm{PGE}_{2}$ discussed above $[4,16]$. Looking at the pathogenesis of this syndrome, the relation of pLT and $\mathrm{PGE}_{2}$ seems to be more important than protein-binding properties of analgesic drugs in AIAs. Previous theories focusing on high pLT levels of bronchoalveolar [6], nasal $[7,8]$ or urinary leukotrienes [9-11], or on the lack ("depletion") of $\mathrm{PGE}_{2}$ [4] alone cannot explain all phenomena. Other mediators, e.g. neuropeptides, are suggested to be modulated by $\mathrm{PGE}_{2}$ [16]. In addition reduced $\mathrm{PGE}_{2}$ synthesis found in AIAs might explain complex changes in the immune system of aspirin-sensitive patients, such as reduced immunoglobulin- $\mathrm{G}_{1}\left(\mathrm{IgG}_{1}\right)$-synthesis [31], as $\mathrm{PGE}_{2}$ is known to modulate immunoglobulin synthesis [32].

Considering the biochemical interdependence of prostaglandin- $\mathrm{E}_{2}$ and peptidoleukotrienes and the typical "profile" of both mediators in aspirin-intolerant asthmatics and controls, the mathematical relation of both eicosanoids was analysed (fig. 6). In all aspirin-intolerant subjects this relation was below 1.0, before and after challenge. Before challenge, the relation was over 200 in normal subjects and in aspirin-tolerant asthmatics over 15. After challenge the relation was over 5.0 in both groups. A prostaglandin- $E_{2} /$ peptidoleukotriene relation below 1.0 was typical for aspirin-intolerant asthmatics and distinguished them from all other groups, e.g. aspirin-tolerant asthmatics.

\section{Acknowledgement. The authors thank M.} Hembera for her technical assistance.

\section{References}

1. Samter M, Beers RF. Intolerance to aspirin. Clinical studies and considerations of its pathogenesis. Ann Intern Med 1968; 60: 276-284.

2. Widal F, Abrami P, Lermoyez J. Anaphylaxie et idiosyncrasie. Presse Med 1922; 30: 189-193.

3. Stevenson DD, Simon RA. Aspirin sensitivity: respiratory and cutaneous manifestations. In: Meddleton E Jr, Reed CE, Ellis EF, Adkinson NF, Yunginger JW, eds. Allergy: Principles and Practice. St Louis, CV Mosby, 1988; pp. 1537-1554.

4. Szczeklik A. Prostaglandin $\mathrm{E}_{2}$ and aspirin-induced asthma. Lancet 1995; 345: 1056.

5. Weiss JW, Drazen JM, Coles N. Bronchoconstrictor effects of leukotriene C in humans. Science 1982; 216 : 196-198.

6. Sladek K, Dworski R, Soja J, et al. Eicosanoids in bronchoalveolar lavage fluid of aspirin-intolerant patients with asthma after aspirin challenge. Am J Respir Crit Care Med 1994; 149: 940-946. 
7. Picado C, Ramis I, Rosello J, et al. Release of peptide leukotriene into nasal secretions after local instillation of aspirin-sensitive asthmatic patients. Ann Rev Respir Dis 1992; 145: 65-69.

8. Fischer AR, Rosenberg MA, Lilly CM, et al. Direct evidence for a role of mast cell in the nasal response to aspirin in aspirin-sensitive asthma. J Allergy Clin Immunol 1994; 94: 1046-1056.

9. Kumlin M, Dahlén B, Björck T, Zetterström O, Granström E, Dahlén SE. Urinary excretion of leukotriene $\mathrm{E}_{4}$ and 11-dehydro-thromboxane $\mathrm{B}_{2}$ in response to bronchial provocations with allergen, aspirin, leukotriene $\mathrm{D}_{4}$, and histamine in asthmatics. Am Rev Respir Dis 1992; 146: 96-103.

10. Smith CM, Hawksworth RJ, Thien FCK, Chrisrie PE, Lee TH. Urinary leukotriene E4 in bronchial asthma. Eur Respir J 1992; 5: 693-699.

11. Christie PE, Tgagari P, Ford-Hudchinson AW, et al. Urinary leukotriene E4 after lysine-aspirin inhalation in asthmatic subjects. Am Rev Respir Dis 1992; 146: 15311534.

12. Bonne C, Moneret-Vautrin DA, Wayhoff $\mathrm{M}$, et al. Arachidonic acid metabolism and inhibition of cyclooxygenase in platelets from asthmatic subjects with aspirin intolerance. Ann Allergy 1985; 54: 158-160.

13. Juergens UR, Christiansen SC, Stevenson DD, Zuraw BL. Arachidonic acid metabolism in monocytes of aspirin-sensitive asthmatic patients before and after oral aspirin challange. Allergy Clin Immunol 1992; 90: 636-645.

14. Sladek K, Szczelklik A. Cysteinyl leukotrienes overproduction and mast cell activation in aspirin-provoked bronchospasm in asthma. Eur Respir J 1993; 6: 391-399.

15. Dahlén B, Dahlén SE. Intolerance reactions to NSAIDs. In: Basomba A, Sastre J, eds. XVI European congress of allergology and clinical immunology ECACI '95, Proceedings I. Bologna, Monduzzi Editore, 1995; pp. 821828.

16. Pavord ID, Tattersfield AE. Bronchoprotective role for endogenous prostaglandin $E_{2}$. Lancet $1995 ; 345$ : 436-438.

17. William WR, Pawlowicz A, Davies B. In vitro test for the diagnosis of aspirin-sensitive asthma. J Allergy Clin Immunol 1990; 86: 445-451.

18. Ferreri NR, Howland WC, Stevenson DD, Spiegelberg HL. Release of leukotrienes, prostagalndins, and histamine into nasal secretions of aspirin-sensitive asthmatics during reaction to aspirin. Am Rev Respir Dis 1988; 137: 847-854.

19. Schmitz-Schumann M, Schaub E, Virchow C. Inhalative Provakation mit Lysine-Acetylsäure beim AnalgetikaAsthma-Syndrom. Prax Klin Pneumol 1982; 36: 17-21.
20. Stevenson DD, Pleskow WW, Simon RA, et al. Aspirin sensitive rhinosinositis asthma: a double blind crossover study of treatment with aspirin. J Allergy Clin Immunol 1984; 73: 500-507.

21. Smith WL. Prostanoid biosynthesis and mechanisms of activation. Am J Physiol 1992; 263: F181-F190.

22. Reinke M, Hoppe H, Röder T, Bestmann HJ, Molenhauer $\mathrm{J}$, Brune K. A monoclonal antibody against the sulfidopeptide leukotrienes $\mathrm{LTC}_{4}, \mathrm{LTD}_{4}$ and $\mathrm{LTE}_{4}$. Biochim Biophys Acta 1991; 1081: 274-278.

23. Brune K, Reinke M, Lanz R, Peskar BA. Monoclonal antibodies against E- and F-type prostaglandins. FEBS Lett 1985; 186: 46-50.

24. Schäfer D, Lindenthal U, Wagner $M$, Bölcskei PL, Baenkler HW. Effect of prostaglandin $E_{2}$ on eicosanoid release by human bronchial biopsy specimens from normal and inflamed mucosa. Thorax 1996; 51: 919-923.

25. Marcus AJ. Eicosanoids: transcellular metabolism. In: Gallin JI, Goldstein IM, Snyderman R, eds. Inflammation: Basic Principles and Clinical Correlates. New York, Raven Press, 1988; pp. 129-137.

26. Samuelsson B, Goldyne M, Granström E, Hamberg M, Mannerström S, Malmsten C. Prostaglandins and thromboxanes. Ann Rev Biochem 1978; 47: 997-1029.

27. Ham EA, Soderman DD, Zanetti ME, Dougherty HW, McCauley E, Kuehl FA. Inhibition by prostaglandins of leukotriene B4 release from activated neutrophils. Proc Natl Acad Sci USA 1983; 80: 4349-4353.

28. Weller PF, Monahan-Earley RA, Dvorak HF, Dvorak AM. Cytoplasmatic lipid bodies of human eosinophils. Subcellular isolation and analysis of arachidonate incorporation. Am J Pathol 1991; 138: 141-148.

29. Dvorak AM, Morgan ES, Tzizik DM, Welier PF. Prostaglandin endoperoxide synthase (Cyclooxygenase): ultrastructural localization to nonmembrane-bound cytoplasmatic lipid bodies in human eosinophils and 3T3 fibroblasts. Arch Allergy Immunol 1994; 105: 245-250.

30. Meade EA, Smith WL, DeWitt DI. Differential inhibition of prostaglandin endoperoxide synthase (cyclooxygenase) isozymes by aspirin and other non-steroidal antiinflammatory drugs. J Biol Chem 1993; 268: 6610-6614.

31. Szszeklik A, Schmitz-Schuman M, Nizankowska E, Milewski M, Roehlig F, Virchow CHR. Altered distribution of $\mathrm{IgG}$ subclasses in aspirin-induced asthma: high $\mathrm{IgG}_{4}$, low $\mathrm{IgG}_{1}$. Clin Exp Allergy 1992; 22: 283287.

32. Phipps RP, Stein SH, Roper RL. A new view of prostaglandin $\mathrm{E}$ regulation of the immune response. Immunol Today 1991; 12: 351-352. 